Wessels, M. (2017). Representations of revolutionary violence in recent Indian and South

African fiction.

Journal of Southern African Studies, 43(5): 1031-1047.

http://dx.doi.org/10.1080/03057070.2017.1337361

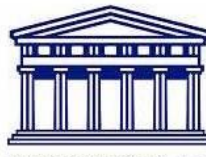

UNIVERSITY of the

WESTERN CAPE

\title{
Representations of revolutionary violence in recent Indian and South African fiction
}

\author{
Michael Wessels
}

\begin{abstract}
Several recent novels in English by Indian and South African authors explore the theme of violent political resistance to the entrenched injustices of the hierarchical Indian social order and South Africa's institutionalised system of racial and economic domination, respectively. This article will investigate and compare the ways in which this theme is treated in four novels: Jhumpa Lahiri's Lowland (2013), Neel Mukherjee's Lives of Others (2015), Mandla Langa's The Texture of Shadows (2014) and Nkosinathi Sithole's Hunger Eats a Man (2015). The first two chart the consequences for their protagonists of their participation in the Naxalite insurrection in the late 1960s. While Langa's The Texture of Shadows does not question the decision to engage in armed struggle against the apartheid regime, it refuses to evade the bitter consequences of this decision both for individuals and for the country more generally. Nkosinathi Sithole's Hunger Eats a Man situates the theme of resistance in relation to the extreme poverty and inequality of the contemporary South African countryside. The comparative approach followed in this article reveals continuities in the representation of resistant violence in the Indian and South African texts in terms of its consequences both for individuals and for post-revolutionary society. At the same time, the comparison exposes significant disjunctions relating to national and generational histories, political ideologies and the ways in which race, class, caste and gender intersect with political resistance in the two countries, as these concerns are imagined in fiction.
\end{abstract}

\section{Introduction}

There are compelling reasons for exploring the theme of political violence in contemporary writing from India and South Africa. ${ }^{1}$ Political violence, whether it be the war in Kashmir and the ongoing Naxal insurrection in India, or the service delivery and student protests in South Africa, continues to be a topical question in both countries. While one must use caution when identifying tendencies from small samples of literature, the very fact that a number of contemporary authors are revisiting histories of violent political resistance suggests that the novels resonate with current anxieties about oppression and inequality, and forms of resistance

\footnotetext{
1 The terms 'counter-violence', 'resistant violence' and 'revolutionary violence' are used interchangeably in this article. 'Counterviolence' is commonly used in the literature on violence to provide a rationale for violent resistance to the violence inherent in the dominant social and economic order. 'Resistant violence' carries the same signification. 'Revolutionary violence' describes the organised form of counter-violence that both the Naxal insurrection and the armed wing of the African National Congress, Umkhonto we Sizwe, adopted.
} 
to them. Despite the differences in the histories and nature of the political movements discussed in the selected novels - and Hunger Eats a Man points towards new forms of organised resistance rather than examining older ones - the Indian and South African novels share enough common ground to form a basis of a discussion about representations of violence, both systemic and resistant, and also about representations of the consequences of violence on both individuals and societies.

Predictably, discussing the novels from the two countries together in relation to the problematic of political violence reveals commonalities but also important differences in their treatment of history and the class position of the revolutionary agents. After all, the insurrection described in what have been dubbed 'Naxal novels'2 provides a very inexact parallel with the African National Congress's (ANC) armed struggle against apartheid that is at the core of Langa's novel. For a start, the ANC's armed struggle had wide support among the country's majority population and was supplemented by, or, more accurately perhaps, was supplementary to, other forms of struggle, nationally and internationally, including civil disobedience. The Naxalite movement has never been a mass national movement of resistance. The two Indian novels portray a very particular phase of the Naxalite struggle in the late 1960s, when middle- class students joined the Maoist insurrection in West Bengal and the tribal belt of Orissa. The revolutionary protagonists in the novels are not direct victims of oppression themselves; in some sense they commit class suicide when they follow the dictates of conscience. The counterparts of this sort of revolutionary in South African literature might more accurately be the white liberals of the Armed Resistance Movement (ARM) of the early 1960s, explored in an earlier generation of South African novels, Nadine Gordimer's The Late Bourgeois World the most prominent among them, rather than the Umkhonto we Sizwe (MK) operatives and township activists of Langa's novel or the rural poor of Sithole's book. Again the equation is inexact: ARM aimed their violence at installations, rather than targeting policemen, landlords and other symbols of power, as the revolutionaries in the Naxal novels do. Their small-scale activities were quickly snuffed out by the state. The Naxalite insurrection continues to this day, although it is no longer characterised by the participation of significant numbers of young urban intellectuals.

Neither the ANC's MK nor the Naxalites have been the only organisations to use political violence as a strategy of resistance in their respective countries. The Pan Africanist Congress' armed wing, Poqo ('pure' or 'alone' in isiXhosa), later known as the Azanian People's Liberation Army (APLA), was formed in 1961, the same year as MK, following the Sharpeville massacre. While the mainstream Indian nationalist movement, the Indian National Congress, did not take up arms, numerous examples exist of armed resistance to both the colonial and postcolonial orders in 20th-century India, from the Indian National Army of Subhas Chandra Bose, which joined forces with Germany and Japan against Britain in the Second World War, to the

${ }^{2}$ N. Martyris, 'The Naxal Novel', Dissent, 61, 4 (2014), pp. 38-44. 
Communists of northern Kerala, 3 the independence insurgents in Kashmir, and other regional movements, such as the Gorkha Liberation Front in north-east India. It is the Naxal insurrection, though, that has received the most sustained attention from contemporary novelists writing in English in India, a phenomenon that Pavan Kumar Malreddy attributes in part, at least, to the influence of Arundhati Roy's travelogue Walking with the Comrades 4 and the allure of Roy's 'enchanted solidarity' with the movement, an enchantment that does not survive its rigorous examination in the two novels.5

My discussion employs the notion of objective and subjective violence developed by Slavoj Žižek and Étienne Balibar to consider how each of the novels portrays the conditions of systemic violence as justifications for the resort to organised resistant violence. Žižek's influential analysis hinges on a distinction between directly visible violence, which he terms 'subjective violence', and the invisible 'objective violence' inherent in both the symbolic order of language and in the 'systemic violence' that attends the 'smooth functioning of our economic and political systems', the violence that is 'inherent to this "normal" state of things'. Subjective violence, or violence with a subject, is rendered visible because it is a disruption of the "normal" peaceful state of things' and has an identifiable subject, whether an individual or a group. ${ }^{6}$ The counter-violence of the oppressed becomes 'divine violence' 7 when it spontaneously disrupts the order imposed by the law, usually as a retributive act of self-defence, rather than resulting from planned, ideologically driven revolutionary action. Objective violence operates chiefly by means of 'subtle forms of coercion that sustain relations of domination and exploitation, including the threat of violence'. ${ }^{8}$ The effects of objective violence are often insidious and slow. A good example is the 'slow violence' of environmental destruction. 9 Oppressive structures and systems are violent in so far as they produce effects as harmful as those produced by direct acts of violence. Climate change, for example, causes extinctions and undermines human ways of life. Balibar argues that both objective and subjective violence become extreme violence when they cross a threshold, rendering life intolerable. This results in excessive suffering or trauma on the part of the victims. In the case of subjective violence, it also entails an intention to act with cruelty on the part of its perpetrators. Extreme violence is signalled in the novels, I will suggest, by the presence of a non-functional, gratuitous element to the violence.

\footnotetext{
${ }^{3}$ See D. Menon, 'A Prehistory of Violence? Revolution and Martyrs in the Making of a Political Tradition in Kerala', South Asia: Journal of South Asian Studies, pp. 662-77.

${ }^{4}$ P. Malreddy, 'Solidarity, Suffering and "Divine Violence": Fictions of the Naxalite Insurgency', in A. Tickell (ed.), South-Asian Fiction in English (Basingstoke, Palgrave, 2016), p. 221.

${ }^{5}$ Malreddy adapts the idea of enchanted solidarity from an essay by Frank Schulze-Engler, in which he argues that some decolonial and postcolonial critics exhibit an uncritical nostalgia for the workers' and anti-colonial struggles of an earlier era. See F. Schulze-Engler, 'Once Were Internationalists? Postcolonialism, Disenchanted Solidarity and the Right to Belong in a World of Globalized Modernity', in P. Kumar Malreddy, B. Heidemann O.B. Laursen and J. Wilson (eds), Reworking Postcolonialism: Globalization, Labour and Rights (Basingstoke, Palgrave, 2015), pp. 19-35.

${ }^{6}$ S. Žižek, Violence (New York, Picador, 2008), pp. 1-2.

7 Žižek derives this term from Walter Benjamin's essay 'Towards the Critique of Violence' (1921); see M. Bullock and M. Jennings (eds), Walter Benjamin: Selected Writings, Vol. 1, 1913-1927 (Cambridge, Mass., Harvard University Press, 1996), pp. 236-52.

${ }^{8}$ Žižek, Violence, p. 8.

${ }^{9}$ See R. Nixon, Slow Violence and the Environmentalism of the Poor (Cambridge, Mass., Harvard University Press, 2011).
} 
Žižek argues that the obsessive focus on subjective violence in the media deflects attention away from objective violence, which becomes the normalised background against which subjective violence forms a spectacular and irrational deviation. While the novels under consideration here are careful not to conceal the objective violence that gives rise to resistant violence, the nature and origin of objective violence is located differently in the novels from the two countries. Žižek insists on the need to 'thoroughly historicise' objective violence. ${ }^{10}$ He comes close to conflating objective violence with capitalism when he argues that it differs fundamentally from 'pre-capitalist socio-ideological violence' precisely because its objective character derives from 'the self-propelling metaphysical dance of capital'. ${ }^{11}$ In postcolonial literature generally, racism and colonialism are inseparable from capitalism but are not reducible to it. In the South African novel, white rule - and the dispossession, forced removals and racism that have accompanied it for four and a half centuries, culminating in apartheid and racial capitalism - forms the basis of the systemic injustice against which violent resistance is harnessed. A notable feature of a number of Indian novels is that they establish a greater degree of continuity between the systemic violence of the pre-colonial, colonial and postcolonial periods than South African novels do. A corollary of this is that the system of objective violence is understood to be integral to the private or domestic sphere as much as it is to the sphere of the political and the economic. Balibar describes the heterogeneity of extreme violence:

it covers phenomena such as genocide and torture but also includes 'the indefinite repetition of certain habitual dominations at the invisible or indiscernible limit of violence'. The latter operates at 'the very foundations of society or culture'. ${ }^{12}$ The domestic subordination of women is the primary exemplar of this phenomenon. A system of objective violence that so thoroughly pervades the social structure that there is no possibility of opposing it and which appears as part of the order of reality itself, of custom and tradition, describes the situation found in such celebrated Indian novels such as Rohinton Mistry's A Fine Balance and Arundhati Roy's God of Small Things. In the South African novel, the system of racial injustice and the poverty and inequality that are its adjuncts impinge on the domestic sphere and on the intimate lives of the novel's protagonists, but these spheres themselves are not, for the most part, seen as integral to the structure of oppression. Race in the South African novel is usually the primary signifier of oppression even as it intersects with class and gender.

It is the equation of structural or systemic injustice with violence that often provides the justification for counter-violence, but this equation does not pass untested in the novels. Harm is caused by both subjective and objective forms of violence, but the agents of subjective violence are more easily identifiable. It could be argued that employing counter-violence against them constitutes a defence. Many more people participate in violent systems than engage directly in visible acts of subjective violence, often unwittingly or because room for manoeuvre outside the system is limited. Whether or not it is justified to impute the same degree of moral liability

10 Žižek, Violence, p. 10.

${ }^{11}$ Ibid., p. 11.

12 É. Balibar, 'Violence and Civility: On the Limits of Political Anthropology', Differences, 20, 2/3 (2009), p. 11. 
to people participating in a harmful system, such as capitalism, as to the agents of subjective violence emerges as a theme in the novels. The question of intention to do harm is critical here, as is the 'slowness' of the effects of the violence. Harry van der Linden argues that 'the range of options available to the victims in addressing' systemic violence is greater than is the case with subjective violence and includes 'protests, boycotts, collective strikes, lobbying and electoral action'. ${ }^{13}$ It is debatable, though, whether the conditions that prevail for the downtrodden in either the Indian or the South African novels allow for these options to be exercised.

Attention will also be given to the actual representations of physical violence in the novels, especially by the revolutionaries themselves. Malreddy asks, in response to the brutality of killings carried out by a later generation of Naxalites in the 1990s, how 'we make sense of this seemingly excessive violence?'14 It is important to consider why the revolutionary protagonists of the novels bring an unnecessary degree of cruelty to the violence in which they participate and also why the authors choose to represent them doing so. The readers' response to specific acts of violence, I will argue, is directed by the detail with which they are described and also by the degree to which they might be characterised as gratuitous. The novels reveal that the sort of enchanted identification with a movement that requires a demonstration of solidarity in the form of the use of extreme violence results, in the novels, in disenchantment at the level of representation.

\section{Two Indian Novels}

In both The Lowland and The Lives of Others, the structures of caste, gender and class inequality provide the conditions of objective violence that prompt their young middle-class protagonists, Udayan and Supratik, to throw in their lot with the Naxal movement, as scores of university students did in the late 1960s and early 1970s, inspired by Charu Majumdar and Kanu Sanyal. Both Udayan and Supratik first experience injustice in the domestic and social worlds in which they grow up, but are politically radicalised at university. The question of individual choice and political commitment is central to both novels.

In The Lowland, two brothers, Subhash and Udayan, respond very differently to the same social and political environment. They are inseparable, and yet only Udayan is drawn to the Naxalite revolution. Subhash feels out of place when taken by Udayan to political rallies. After Subhash moves to the United States to pursue his studies, the brothers keep in touch by letter, but Udayan doesn't mention his revolutionary activities, partly for reasons of security but also because he knows that Subhash would not approve. After Udayan is killed by the police, Subhash reflects that his brother 'had given his life to a movement that had been misguided, that had caused only damage .... ${ }^{15}$

\footnotetext{
${ }^{13}$ H. van der Linden, 'On the Violence of Systemic Violence: A Critique of Slavoj Žižek', Radical Philosophy Review 15, 1 (2012), p. 17.

${ }^{14}$ Malreddy, 'Solidarity, Suffering', p. 218.

15 Jhumpa Lahiri, The Lowland (London, Bloomsbury, 2013), p. 115.
} 
Already as a boy Udayan is angered by the contrast between the world inside the exclusive Tolly club near the boys' home and the poverty that surrounds it. Later, as an adult, he is involved in bombing the same club. His boyhood outrage at inequality and oppression increases as he gets older. His experiences in the countryside during a period of political education confirm this anger:

He met tenant farmers living in desperation. People who resorted to eating what they fed their animals. Children who ate one meal a day. Those with less sometimes killed their families, he was told, before ending their own lives.... He saw how the system coerced them. How it humiliated them. How it had stripped their dignity away. ${ }^{16}$

The reader learns of the full extent of Udayan's revolutionary activities only in the final pages of the novel, in which he becomes the focaliser of the third-person narration and we enter his experience of being shot in cold blood by the police in front of his wife, mother and father. Udayan, we gradually learn, has followed a series of steps that draws him deeper into the Naxalite movement. At first this engagement consists of non-violent protests against caste injustice, political education and time spent in the 'countryside to further indoctrinate himself'. ${ }^{17}$ Then there follows a period in which he learns to make bombs and to stake out targets. Only later does he participate directly in acts of violence, and only in the final pages of the book do we learn something of the nature of these acts and of their corrosive effects on his conscience. Unlike the deeply flawed Supratik in Lives of Others, Udayan is tragically aware of the consequences of his choices. His enchanted solidarity with the Naxalites does not survive his initiation into its violent practices. Not long before his death he confides his feelings of guilt to his wife, Gauri:

I can't become a father, Gauri.

After a moment he added, Not after what I've done. What have you done. He wouldn't say ... ${ }^{18}$

Udayan's death, psychological as much as it is physical, begins with his presence at the killing of the policeman: '[t]hat blood had not belonged only to the police officer, it had become a part of Udayan also. So that he'd felt his own life begin to ebb, irrevocably, as the policeman lay dying in the alley'.19 While he does not actually kill the man himself, '[h]e had gone as close as he could, he had dipped his hand in the fresh blood of that enemy, writing the party's initials on the wall as the blood leaked down his wrists'. ${ }^{20}$ This description is notable for the visceral nature of its details and the inscription of violence not only on the walls but on Udayan's psyche and conscience. His participation in the killing provides a stark contrast with the tenderness he displays towards his family and towards Gauri, a quiet

\footnotetext{
${ }^{16}$ Ibid., p. 336.

${ }^{17}$ Ibid., p. 335.

${ }^{18}$ Ibid., p. 322.

${ }^{19}$ Ibid., p. 339

${ }^{20}$ Ibid., p. 338.
} 
philosophystudent whom he marries for love and from whom he hides the full extent of his involvement in revolutionary violence. The revolutionary slogans that Udayan has imbibed begin to sound increasingly false to him as time goes on. He observes, in relation to the Naxalite uprising, that 'it had fixed nothing, helped no-one'; ${ }^{21}$ it has only entrenched the position of the powerful. His guilt at the policeman's death is not relieved by Charu Majumdar's assertion that policemen 'are not Indians, they do not belong to India'. Udayan is no longer convinced that '[e]ach annihilation would spread the revolution. Each would be a forward step', ${ }^{22}$ or that revolutionary violence 'was a force of liberation, humane'. ${ }^{23}$ Majumdar's assertion that objective violence justifies subjective resistant violence no longer satisfies Udayan. An individual policeman is an inadequate metonym for a system. He experiences the full force of the tragic dilemma that faces the revolutionary: he can 'renounce neither the struggle for emancipation nor resistance (interior or exterior) to the nihilism of violence'. ${ }^{24}$

Udayan himself is dead by the early 1970s, but the consequences of his political involvement continue to play out in Gauri's life. She is first isolated in Udayan's family home in Calcutta by Udayan's parents, who unfairly associate her with their son's death and his revolutionary politics. She is then rescued by her brother-in-law, Subhash, who marries her and takes her to the United States, where she gives birth to Udayan's child, Bela. Gauri, however, simply goes through the motions of marriage and family life, increasingly retreating into her books and academic studies. She spends as much time apart from her daughter as she can. Eventually she runs away from home, leaving nine-year-old Bela for Subhash to raise.

For much of the novel, Gauri's actions seem driven by her inability to form an emotional attachment because of the trauma of her enforced separation from Udayan, exacerbated by the fact that she witnesses his execution. She retreats into the realm of abstract thought, writing a book on the philosophy of Hegel, moving as far as she can from the messy world of revolutionary politics. It is only towards the end of the book that we learn how Udayan involved her in the policeman's killing without her knowledge. Her information about the man's daily movements allows Udayan and his comrades to plan the policeman's death, a fact that haunts Gauri for the rest of her life. The policeman, for Gauri, is not reducible to his role in the system. She bears the knowledge of her complicity in the man's murder alone: '[s] he was the sole accuser, the sole guardian of her guilt. Protected by Udayan, taken away by Subhash. Sentenced in the very act of being forgotten, punished by means of her release'. ${ }^{25}$ Her love for Udayan is mixed with a sense of betrayal. It is accusation that he sees in her eyes when he looks at her minutes before his death and realises 'that he was no hero to her. He had lied to her and used her'. ${ }^{26}$

\footnotetext{
${ }^{21}$ Ibid., p. 334.

22 Ibid., p. 337.

${ }^{23}$ Ibid., p. 338.

${ }^{24}$ Balibar, 'Violence and Civility, p. 10.

${ }^{25}$ Lahiri, The Lowland, p. 320.

${ }^{26}$ Ibid., p. 338.
} 
In Malreddy's view, Lahiri makes the death of Udayan stand in for the failure of Naxalism itself. Udayan, representative of the middle-class intellectual during a very particular phase of the Naxal struggle, becomes a metonym of the movement as a whole. The people on whose behalf he and his comrades carry out their activities appear in the book only as abstractions. This leaves 'no room for the subjects of objective violence to represent their pathos, their deaths and their suffering which is expiatory, divine and non-transcendental' (emphases in original). Udayan's enchanted solidarity is not an effective basis for a revolution, and the Naxal movement should not be reduced to it. As a result, argues Malreddy, Lahiri's novel 'fails to resolve such representational impasses of the agency as well as the agents of divine violence'. ${ }^{27}$ An turns to political violence through a personal sense of injustice and youthful idealism, whereas the direct victims of oppression turn to acts of retributive violence as a result of the everyday conditions and violence they experience. Their counter-violence has an element of divine violence that is absent from the ideologically driven violence of the middle-class protagonist. We might say that Udayan's prior experience of violence does not coincide with that of the peasants for whom objective and subjective violence are practically equivalent.

In terms of the signifying economy of the novel itself, however, I would argue that Udayan represents a tragic dimension that is implicit in political commitment more broadly during certain historical junctures. While people like Udayan choose to join resistance movements. they do not themselves choose political violence. Their sense of justice leads them to join movements that have already adopted violence as a tactic. It is a choice determined largely by their peers and the context in which they find themselves. As Balibar notes 'what creates the capacity for resistance to violence in individuals ... is the set of relations that they always maintain with other individuals'. ${ }^{28}$ Udayan's relations with the peasants might entail an element of inauthentic solidarity, but his relations with radicalised students in Calcutta do not. Initially, Udayan and his friends choose justice not violence, but the consequence of this choice leads them to participate in acts of violence that have fatal consequences, physically and morally, both for themselves and for the people around them. In another historical context, violent resistance might not have been an option at all. Strategies other than violence might also have been more readily available. Another possibility might have been one in which they found themselves in a situation in which a less abstract relationship between objective and subjective violence prevailed, thereby investing their actions with a greater degree of socially sanctioned heroism. Such conditions exist for the MK soldiers in The Texture of Shadows.

Udayan's recourse to violence is tragic also because of a discrepancy between the goals and the means available to achieve them. The means cannot justify the end because the end, as Udayan comes to realise, is not achievable. In this respect, the novel is a good example of Ronit Frenkel's assertion that many South African and Indian postcolonial novels are premised on a

${ }^{27}$ Malreddy, 'Solidarity, Suffering', p. 226.

${ }^{28}$ Balibar, 'Violence and Civility', p. 19. 
sense of postcolonial pathos. ${ }^{29}$ Kiran Desai's Inheritance of Loss, about the Gorkha independence movement in Sikkim, for example, turns on a politics of loss in which the Gorkha struggle is seen as hopeless and its revolutionaries as naive. The sort of political hope that survives in Lahiri's novel does not rescue it from Frenkel's critique. Political commitment is displaced to the US and to the next generation. Udayan's daughter, Bela, who grows up thinking Subhash is her father, inherits her biological father's political idealism. In her case this translates into environmental activism. Like her father, Bela does more than talk; she labours on organic farms, and in 'blighted' neighbourhoods she helps 'to convert abandoned properties into community gardens'.30 While her idealism is free of the tragic historicalobjective correlative that blights Udayan's life, it makes Subhash uneasy. He admires his adopted daughter's commitment to a cause, but it also reminds him of his brother: like Udayan, Bela 'could be self-righteous' and her work merges 'with a certain ideology'. Although Udayan felt that he could never produce children, something of his revolutionary spirit lives on in the daughter who is born after his death. Gauri's tentative reconciliation with Bela, still only implicit at the end of the novel, also suggests a greater incorporation and acceptance of the oppositional spirit of Udayan into the fabric of the contemporary, a development paralleled by Gauri's growing interest in the subsequent history of the Naxalite movement. She recognises that the failure of Udayan and his generation 'remains an example, the ember managing to ignite another generation'31

While this tentative reclamation of the Naxalite legacy is paralleled in the ending of Lives of Others, in neither novel does the ending sufficiently outweigh what has come before, to provide a vindication for political violence. Other parallels can also be found between the two novels. Like Udayan, Supratik - the eldest grandson of Prafullanath, the head of the family and innovative founder of the family business - joins the Naxalites as a student in Calcutta, later spending two years working among tribal peasants before returning to Calcutta to organise the urban resistance to state power in the city. Supratik's politicisation stems, in part at least, from his early sense of injustice in the intimate realm of the family. Like Udayan, Supratik is the only one of his family whose sense of injustice leads to solidarity with the Naxalites. His brother, Suranjan, also a student, falls into heroin addiction, ${ }^{32}$ while a reclusive cousin becomes a mathematics professor at a precociously early age and later wins the Nobel prize.33

The novel portrays the micro-levels of power within the domestic sphere in forensic detail. Supratik's story of the Naxalite struggle alternates with the stories of the struggles of the people who inhabit the Ghosh household in Calcutta. This household is hierarchically structured - into masters and servants, with divisions among both masters and servants. His younger aunt, Purba, with whom Supratik is secretly in love, is forced to live in a room on the ground level with the servants after her husband, Somnath, is beaten to death by a group of tribal

\footnotetext{
${ }^{29}$ R. Frenkel, 'The Politics of Loss: Post-Colonial Pathos and Current Booker Prize-Nominated Texts from India and South Africa', Scrutiny 2: Issues in English Studies in Southern Africa, 13, 2 (2008), p. 87.

${ }^{30}$ Lahiri, The Lowland, p. 224.

${ }^{31}$ Ibid., p. 275.

${ }^{32}$ Ibid., p. 246.

${ }^{33}$ Ibid., p. 496.
} 
Santhals for trying to rape a local woman, a classic act of divine justice with which the political violence of Supratik and his Naxal group compares unfavourably. The actual servants, including Madan-da, a surrogate parent to the children of the house and a key cog in the smooth functioning of the domestic order, inhabit cramped quarters, eat different food, work long hours and seldom see their families, who live in distant villages.

The pathological effects of power that Supratik first experiences in the unequal order that prevails within the wealthy Ghosh extended family of Calcutta are greatly magnified in the harsh conditions he finds among the Adivasi smallholders in the tribal belt of Orissa, among whom he is sent to work after he joins the Naxalites. He details these in unposted letters to an unknown recipient, revealed late in the novel as Purba. The Adivasi people are virtually owned by a class of landowners with ties to criminal networks and the police. Story after story tells of dispossession, destitution and suicide, just some of the consequences of the local power structure, with its micro-politics and ready recourse to violence. These intricate human stories provide a contrast with Supratik's Maoist analysis, which reduces the complexity of human relationships to a Manichaean world of class allies and enemies, a discrepancy between theory and life that increasingly comes to accompany many of Supratik's revolutionary actions as well. His increasing dedication to abstract political theory parallels the growing moral ambiguity of his participation in acts of violent retribution against local representatives of institutionalised forms of power.

The Adivasi peasants, the Naxalite leaders believe, require a political education at the hands of vanguard urban revolutionaries like Supratik if they are to begin to resist their oppression. 34 While Supratik does not look down on the villagers and greatly admires their strength and pastoral way of life, both his idealisation of them and his position as political educator mean that the novel reproduces the 'representational impasses' that Malreddy detects in The Lowland, 35 although this dynamic shifts to some degree once the peasants themselves become involved in acts of resistant violence.

Like Udayan, Supratik is torn between ordinary human feeling and revolutionary imperatives. He is deeply troubled by the consequences for the villagers of the assassinations carried out by the Naxalites. $3^{6}$ As he becomes disabused of his revolutionary romanticism, his loyalty to the movement begins to exhibit features of disenchanted solidarity. It is notable, though, that his disenchantment does not follow from moral disgust at his own violent actions, as it does for Udayan in Lowland, but from the brutal reprisals that the violence elicits against the peasants in the area. Supratik's engagement in violence hardens him; it doesn't result in the sort of moral self-loathing or self-awareness that it does for Udayan. When he returns to the family fold after two and a half years in the villages and jungle, he scorns his mother's fears for his safety and sneeringly dismisses his father's concerns about the damage to the family's reputation

\footnotetext{
${ }^{34}$ Malreddy, 'Solidarity, Suffering', p. 218.

${ }^{35}$ Neel Mukherjee, The Lives of Others (London, Vintage, 2015), p. 246.

${ }^{36}$ Ibid., p. 338.
} 
that his revolutionary activities have produced. ${ }^{37}$ But it is his reaction to the remonstrations of the faithful old family servant Madan-da that produces the most discomfort in the reader. Madan-da asks Supratik whether 'being kinder to your near and dear ones - isn't that a bigger thing than doing good for the unknown mass of people?' 38 Supratik's rage at 'being given a lesson in morality by the family's cook' lies directly behind his decision to frame the old man for the theft of jewellery that he himself steals to help fund the revolution. Madan-da is arrested, tortured, and later commits suicide. 39 For Madan-da, betrayed by both Supratik and the hierarchical system he has served so devotedly, resistant violence is not an option; suicide represents his only chance of escaping the fate that objective violence has decreed for him. Supratik's revolutionary commitment here trumps ordinary human decency; it is based on cruelty and petty feelings rather than on a sense of justice.

The violence of the repressive state apparatus is carefully described in the novel, both when the rebellious villagers are being punished and in the course of the torture of Supratik himself at the end of the novel. Despite its extreme brutality, though, it has a purpose - to terrorise the villagers into submission and restore the old order or to force Supratik to inform on his comrades. By contrast, the violence displayed by Supratik and his comrades when assassinating 'class enemies' includes a gratuitously sadistic component:

... he [a local moneylender, pawnbroker and smuggler] starts begging for mercy. What sweet music. We know we're going to slit his bloated stomach, pull out his guts and stuff his mouth with it, but we let him sing for a while.... His stomach was so fat that the hashua sprang back when I tried to stick it in. Then I thought it would be more fun to slit his belly open only a little bit, like surgeons do during an operation. ${ }^{40}$

Supratik's enjoyment in this killing is an index of the moral harm produced by his political choices. He crosses the threshold into extreme violence, revelling in cruelty for its own sake. Unlike the constant representation of images of subjective violence in the media, which, Žižek suggests, is intended to deflect attention away from the much greater effects of objective violence, the representation of subjective violence is this novel is generally restrained, so that a description such as this one is profoundly shocking.

Broken by torture at the end of the novel, Supratik regrets his involvement in the movement, less from the sort of moral remorse experienced by Udayan than from his own abjection. In both cases, though, we might recall Gandhi's warning 'that nothing enduring can be built upon violence'. ${ }^{41}$ The novels appear to contradict the idea that revolution can 'kill its way to utopia'. ${ }^{2}$ In her discussion of these and other Naxal novels, Martyris describes the beginnings

${ }^{37}$ Ibid., p. 420.

${ }^{38}$ Ibid., p. 426.

${ }^{39}$ Ibid., p. 495.

${ }^{40}$ Ibid., p. 343.

${ }^{41}$ M. Gandhi, Selected Writings of Mahatma Gandhi, selected and introduced by Ronald Duncan (London, Faber and Faber, 1951), p. 249.

${ }^{42}$ Martyris, 'The Naxal Novel', p. 39. 
of 'a movement to support non-violent Adivasi resistance' led by ex-Maoists such as novelist Dilip Simeon who, in his own Naxal novel, repeats a question from Dostoevsky's The Brothers Karamazov: '[i]f all mankind could realise happiness by torturing to death a single child, would this act be morally justified?'43 Madan-da's death elicits a similar question in Mukherjee's novel. Despite the critique of revolutionary violence that is present in Lives of Others, its ending might be interpreted, nevertheless, as a muted endorsement of its continued use in the context of conditions in the tribal areas. As the novel takes leave of the vanguard moment of the early years of the Naxal revolution, it looks ahead to the continuing struggles today of the communities that have thrown in their lot with the Naxalites, ending with an epilogue in which, 30 years after Supratik is murdered by the police, a group of fighters, now all drawn from the ranks of the villagers rather than the urban intelligentsia, prepare to blow up a train. They are led by a woman whose younger sisters have been raped and murdered by the police. She knows that she will die for the cause sooner or later but it was better to die fighting, like a cornered wildcat, than crushed underfoot like an unseen worm'. 44 The novel suggests here that resistant violence is a regrettable but inevitable consequence of systemic injustice. The revolutionaries lay the charge, knowing that in 'three hours, well before dawn breaks, the Ajmer-Kolkota Express, carrying approximately 1,500 people, is going to hurtle down these tracks'. 45 By ending with this image, the reader is left to ponder the price of revolutionary violence and also to consider the inevitability of its gathering momentum in the context of the intractable violence of the social, economic and political order.

In Malreddy's view, Udayan cannot legitimately adopt a position as subject (victim) of systemic violence because he possesses a 'privileged, inaccessible relationship to the domain of objective violence'. ${ }^{4646}$ The problem in both the Naxal novels, in my reading, is not that the protagonists are not subject to objective violence but rather that they are subject to different forms of objective violence from those experienced by the villagers or slum dwellers on whose behalf they fight. Their experience of objective violence does not occur in the context of the community of suffering to whom they transfer their solidarity. This split is not present in the South African novels discussed next; 'the subjects of objective violence' 4747 are clearly also the agents of revolutionary violence.

\section{Two South African Novels}

Numerous South African texts written in the apartheid era, but also increasingly those written in the post-apartheid era, explore the theme of revolutionary commitment and the nature of oppositional violence. 48 As in Indian fiction, political commitment, particularly dedication to armed struggle, has consequences not only for society at large but also in the private realm, in the minds and psyches of individuals and in interpersonal relations. Revolutionary engagement

${ }^{43}$ Ibid., p. 43.

${ }^{44}$ Mukherjee, 'Lives of Others', p. 503.

${ }^{45} \mathrm{Ibid}$.

${ }^{46}$ Malreddy, 'Solidarity, Suffering', p. 232.

${ }^{47}$ Ibid., p. 228.

${ }^{48}$ A short list would have to include Gordimer's The Late Bourgeois World and Burger's Daughter, Coetzee's Age of Iron, Serote's To Every Birth its Blood and La Guma's The Butcher Bird. 
exacts a heavy price on both individuals and the body politic, an idea conveyed by the title of Achmat Dangor's Bitter Fruit, 49 which tells the story of the breakdown of a family in the post-apartheid era caused primarily by the traumas produced by participation in the struggle. Jacob Dlamini's Askari is a recent work of non-fiction that critically revisits the struggle, its violence and its after-effects in the course of telling the stories of some of the MK operatives who were captured and turned into agents of the apartheid regime.50 As Balibar observes, the forcing of the victims of violence to become its agents constitutes one of the most extreme forms of violence. ${ }^{51}$ It is notable in Langa's novel that it is chiefly the victims of this form of cruelty who perpetrate acts of excessive violence. Like Dlamini's book, The Texture of Shadows demystifies the armed struggle against apartheid and reclaims its suppressed stories. Langa employs fiction to do this, though, making use of formal strategies that capture the confusion, fragmentation and disjunction of the struggle period. Unlike the Naxal novels, The Texture of Shadows describes a successful revolution, albeit one that terminated in a negotiated settlement rather than in the defeat of the old order. Like them, though, it deals with the ambiguous nature and legacy of political violence. Set in the heady period just before Mandela's release, the book shares little of the euphoria and optimism that characterised the period itself. While the struggle, as the novel portrays it, was not short of idealism and self-sacrificing commitment, it was also beset by betrayal, opportunism, gratuitous violence, cruelty and poor leadership. As its title indicates, the novel portrays a world in which things are not always as they appear on the surface and in which morality is not a simple matter of oppressed and oppressor, or of revolutionaries and collaborators; there are many shadowy areas in between. The novel never inhabits the simplistic world of enchanted solidarity.

The Texture of Shadows moves quickly between locations and time periods, frequently digressing from the main narrative to follow a character's memories or experiences. In this way, it conveys the atmosphere, pace and confusion of the struggle period. The novel is constructed also of multiple points of view of the same events. The focalisation shifts with bewildering rapidity. Even the most repellent characters express opinions that are difficult consistently to reject, especially because similarly jaundiced views of both the struggle and the new democratic dispensation are also voiced by characters with moral and political credibility. The characters who invite the reader's sympathy are not always on the right side: Jolene, a young white woman, who is captured by the movement and subjected to torture and repeated rape, is more sympathetically portrayed in some ways than the impressive but distant internal leader, Muzi Thabethe, even though she is part of Pretoria's notorious special forces and holds racist views. These views so repel Nerissa Rodrigues, a senior ANC leader, a chaplain and a character who is sympathetically portrayed, that she finds herself briefly sanctioning the sexual violence to which Jolene has been subjected: '[n]o wonder, Nerissa thought, these despised people were so diligent in inflicting themselves on you, fucking all that whiteness

\footnotetext{
${ }^{49}$ Achmat Dangor, Bitter Fruit (Cape Town, Kwela Books, 2001).

${ }^{50}$ J. Dlamini, Askari: A Story of Collaboration and Betrayal in the Anti-Apartheid Struggle (Johannesburg, Jacana Media, 2014).

${ }^{51}$ Balibar, 'Violence and Civility', p. 17.
} 
out of you'.52 Only a few pages later, though, Nerissa holds the younger woman tenderly, an embrace that quickly turns sexual, perhaps her own way of 'fucking the whiteness' out of Jolene, using love rather than violence.

The structural violence of the South African state and of apartheid itself is largely taken for granted and does not need to be set out in detail. This is true in contemporary South African literature generally, I would suggest, and forms a point of contrast with both Indian literature and earlier periods of South African writing, in which the inequalities, discrimination and violence of apartheid are minutely scrutinised and exposed. The iniquities of apartheid are too well known to need reiteration in Langa's novel; a reference or two to some of its features can stand in for the whole. Colonel Jan Stander, a ubiquitous presence, popping up everywhere from Angola to the townships around Durban, functions as a metonym for the violence of the white state. Reminiscent of the notorious hit-squad leader and commander of Vlakplaas, Eugene de Kock, Stander is involved in torture, assassinations and the activities of the special forces in the Angolan war. Most of the references to white supremacy focus less on the overt physical violence of the system than on its day-to-day psychological effects. Townships, we learn, 'no matter how many names of heroes are emblazoned on their streets, are simply evidence of how thoroughly the white world holds black people in contempt'53

Balibar argues that the prerequisites for 'a demand for anti-violence' are citizenship and 'a proper moment of civility in politics'.54 Clearly, neither of these conditions existed for black South Africans before 1994.

It is thus not surprising that the morality of taking up arms against the systemic violence of the apartheid system is not questioned in Langa's novel. Participating in violent revolution is not in itself morally corrosive, as it is in the Naxal novels.

Many of the MK soldiers are portrayed as brave, resolute, disciplined and humane. Nevertheless the damaging psychological and moral consequences of revolutionary violence on individuals, communities, the ANC itself and the country as a whole are central to the novel's concerns. Not everyone is ennobled by their participation in the struggle, and the country itself is blighted by its legacy. Although The Texture of Shadows is set at the dawn of political freedom, it represents in many ways a critique of the post-apartheid government, tracing the roots of its shortcomings to the struggle period and the fractious nature of the movement in exile: riddled by informers, paranoid and authoritarian, with some of its leaders ready to form alliances with their erstwhile enemies to exploit opportunities in the new South Africa. A hero of the revolution, General Palweni, has entered into a deal with Stander, and the two die together, lynched by a mob of hostel dwellers in the final pages of the novel in a spontaneous act of retributive, divine violence.55 The movement has been heavily

52 Mandla Langa, The Texture of Shadows (Johannesburg, Picador Africa, 2014), p. 220.

${ }^{53}$ Ibid., p. 183.

${ }^{54}$ Balibar, 'Violence and Civility', p. 29

${ }^{55}$ Langa, Texture of Shadows, pp. 365-7. 
compromised by its treatment of political prisoners in its camps. People with legitimate grievances and those pushing to fight inside the country are labelled as traitors and imprisoned along with genuine traitors and apartheid operatives. This system comes to operate as an oppressive order of objective violence itself, backed by the ever-present threat of subjective violence against anyone who voices criticism of it.

Two of the novel's central characters, Django and Mchinda, are part of a group sent to infiltrate South Africa from Botswana. They escape to Kwa Mashu, near Durban, after surviving an attack on their group in the western Transvaal, in which many of their comrades die. They had been set up by Palweni, who makes use of 'a motley crew of askaris, mercenaries, and miscellaneous malcontents cobbled up into a platoon by Colonel Stander' 56 to do his dirty work. Django and Mchinda reflect on the irony that their comrades in arms had survived 'various ambushes on the Eastern Front' 57 only to die at the hands of their own forces as they entered their own country. Earlier, both men had paid a price for rebelling and standing up to the powers-that-be and raising their voices in their campaign to go home and fight the enemy, the SADF. Here they discovered how easy it was to become an enemy among their own forces, and that erstwhile compatriots could be harsher by far than anything the Pretoria regime could muster'. 58

These experiences lead Django to fear for the future. It seems to him 'that the erosion in the calibre of the leadership was directly proportional to the ticking of the clock, the countdown to going back home, God alone knew the kind of riff-raff that would masquerade as leaders in a liberated South Africa'.5959

The men discover that the condition of the movement within the country is little better. Many of its leaders are unreliable - heavy drinkers, for example, or sexually compromised while the youth who make up the self-defence units in the townships are virtually inseparable from the youth gangs that also patrol the streets. It is tempting to agree with Spider, the leader of the Nabobs, a street gang in Kwa Mashu, that '[e]veryone had a crew; the political parties were just a crew on a larger scale. Come to think of it, the government was an organisation of gangsters with crews like the army and the police in uniform' ${ }^{60}$ While Spider is an unreliable informant, the analysis of the novel's more trustworthy informants is hardly more upbeat. Chaplain Nerissa Rodrigues notes that the structures within the country to which the exiles return 'are a bit chaotic. The young people here have not grown up enough to avoid being victims of their own anger'. ${ }^{61}$ While people are 'gung-ho about the future', Nerissa herself feels that 'we'll be caught with our pants down. There are just too many unresolved issues in our lives, so many unmourned corpses, so much destruction. And

${ }^{56}$ Ibid., p. 230.

${ }^{57}$ Ibid., p. 32.

${ }^{58}$ Ibid., p. 33.

${ }^{59}$ Ibid., p. 20.

${ }^{60}$ Ibid., p. 308.

${ }^{61}$ Ibid., p. 157. 
the poverty will be the undoing of any government that takes over this mess' ${ }^{62}$ Her critique of South African prejudices towards other Africans anticipates the violent attacks on foreign Africans in the post-apartheid era: 'her people were just cry-babies and knew fuck-all about hardship. And so they got their jollies out of tormenting the poor foreign African just because they couldn't punish the whites'.63

If anyone represents a moral barometer in the novel, it is Chaplain Rodrigues. Tellingly, she is entrusted by the president of the movement, Oliver Tambo (not actually named in the novel), with a fact-finding trip to the ANC prison section 37 in Angola. Tambo confides to Rodrigues that it pains [him] that there are zealots among us whose practices are inimical to life. They are menacing the Movement, which has, throughout time, preached the sanctity of life. I hear of torture of prisoners - of South Africans - by our own people'.64 The prisoners are classified as 'enemy agents' even though many are guilty only of insubordination or 'breaches of military discipline'. ${ }^{65}$ Nerissa's experience of camp 37 leads her to accuse the movement of duping young men 'into thinking that freedom will come tomorrow from the barrel of a gun. But these young people did not deserve to become cannon fodder any more than they deserved incarceration'.66 Her horror grows when she actually sees the prisoners after they are set free by Thabo Stone, who later re-emerges as Mchinda, in a co-ordinated attack on the camp by another section of the movement: '[a] few hobbled out looking wildly about them.... The air, which had been stuffy and close, was now heavy with the odour of unwashed bodies, human waste and infected wounds'. ${ }^{67}$ 'Is this who we are? What we have become?', Rodrigues asks herself. ${ }^{68}$ She concludes that the '[m]ovement, its armed wing, the People's Army' is in the dock 'because we've sacrificed our humanity on the altar of expediency'. ${ }^{69}$ Her misgivings are echoed by the view of an internal leader and ex-political prisoner, Muzi Thabethe, that the ANC's strategy of assassinations of suspected spies and apartheid agents could lead to 'the People's Army also losing its revolutionary morality by adopting strategies that had earned the apartheid state international condemnation'.70

Nerissa, Django and Thabethe's critiques of the movement and their prescient fears for the future carry moral weight. But the predictions for the future of cynical opportunists like Stander and Palweni prove equally accurate. The two do not survive into the post-apartheid era themselves, but many like them do. Stander plans to be a "beneficiary" of the Movement's victory' ${ }^{71} \mathrm{He}$ is already making the transition from the special forces to organised crime, along with ANC leaders like Palweni, who 'had been given the task of establishing units that would

62 Ibid., p. 158.

${ }^{63}$ Ibid., p. 159.

${ }^{64}$ Ibid., p. 189.

65 Ibid., p. 197.

${ }^{66}$ Ibid., p. 208.

${ }^{67}$ Ibid., p. 217.

${ }^{68}$ Ibid.

${ }^{69}$ Ibid., p. 224.

${ }^{70}$ Ibid., p. 107.

${ }^{71}$ Ibid., p. 243. 
mount bank heists and hijacks'.72 In an echo of the notorious chemical weapons expert, Wouter Basson, who produced ecstasy pills for the South African market, Stander argues, '[w]e will have to think of creative ways to introduce drugs - yes, drugs - into the market, simply because, to take over an economy you have to first undermine its capacity for survival'. Stander observes sarcastically that 'of course there will be violence....

We'll build on the framework already set by the movement itself, where it exhorts the youth to render the country ungovernable'.73 While Stander and Palweni have reason to look forward to a future in which they and their kind can flourish, others are more fearful. A black policeman, Sergeant Mkhize, comments that it is fine for Oliver Tambo to encourage 'people to make this country ungovernable ... if you are preaching from Lusaka'.74 The result, though, will be that post-apartheid South Africa 'is going to need a lot more policemen simply because there have to be armies of us with umbrellas and shovels when the shit comes down'.75 The violence of white supremacy elicits a violent response which, in turn, produces a violent future. Japhet Makhunga, an ex-Robben Island prisoner, expresses it eloquently:

[t]hat's the problem with us ... We've got all these young men whose scrotums are full of the seed of war. We don't read the situation we are in today ... We will take these warriors and put them on our shoulder and thrust their heads into the clouds and then ask them to lead us. And we will again wallow in ignorance, poverty and disease and some of us, in the nottoo-distant future, will be crying for the white man to return, like the Children of Egypt asking to be returned to Egypt. ${ }^{76}$

These forebodings are symbolically embodied by Strella and also by an object, a trunk. Strella represents essential violence, engaging in acts of extreme violence for its own sake. He thrills in the intimacy of close combat:

[t]he long-distance violence, while thrilling in its endorsement of his marksmanship, couldn't match the excitement of close combat, no, correction, intimate killing: pushing the serrated blade into the ribcage, thrusting in that last, pulsating inch, the thrill coursing like an electrical charge down his spine as he would watch life flapping about and then finally ebbing out with a sigh. There is nothing to beat the smell of fresh blood.77

Nerissa does not 'think Strella is a human being ... I just think he's a creation that was sent here to teach us something about evil'. ${ }^{8}$ He brutally kills an old man who has given him a bed for the night in Gaborone, where, like many others, he has fled apartheid South Africa. He joins

${ }^{72}$ Ibid.

${ }^{73}$ Ibid.

${ }^{74}$ Ibid., p. 262.

75 Ibid.

${ }^{76}$ Ibid., p. 318.

${ }^{77}$ Ibid., p. 76.

${ }^{78}$ Ibid., p. 361. 
MK and is trained in Libya before he is turned into an askari by Stander. His group is captured in Angola and imprisoned in the notorious MK prison in sector 37. He escapes and later forms part of the assassination squad that intercepts Mchinda and Django's detachment. By the end of the novel, Palweni and Stander are dead. Their removal gives hope for the new order. Strella, however, remains at large. The narrator, stepping directly into the novel for the first time, tells the reader that he would have liked to tell you everything ended well, that Strella was captured and handed over. It would have given me immense pleasure to stand witness and testify against him'.79 Instead Strella, and the violence he embodies, escapes into the new South Africa.

The trunk carries a potent symbolic force, representing the unresolved and shadowy dimensions of the struggle; it could be described as the unconscious of MK's fight against apartheid, symbolising the suppressed and untold stories of the struggle. The trunk also provides the centre around which the plot is constructed, as an array of groups and individuals compete for its possession. Some people want to destroy documents that the trunk is purported to contain that would incriminate them, while others hope to find evidence that would expose the false charges that led to their imprisonment and torture. Others simply hope that the contents of the trunk will help them to remember the dead. Tellingly, the trunk is never opened, and we do not learn what exactly is in it.

The book ends with a resigned acceptance of the shortcomings of the present. The narrator notes that 'you'll be hard-pressed to find anyone who actively supported the regime; the children of marauders, beneficiaries of today's preoccupation with forgiveness, will evolve a new language of arrogance and self-absolution. We will have to live with that'. ${ }^{\circ}$ At the same time, the narrator insists that the young men who died must not be forgotten; it is necessary to 'scour the terrain of Angola and Mozambique and Botswana and Lesotho - just to name a few arenas where our young people fell - and collect all those bones and bring them home'. The novel acknowledges the inherent ambiguity of revolutionary violence, even as it reminds the country of its debt to the revolutionaries: 'I hope that we'll have time for the people who went to the bush to learn how to bring peace by taking up arms - a paradox, I know'. The novel remains loyal to the struggle and those who sacrificed their lives for it, but this solidarity is thoroughly disenchanted.

Nkosinathi Sithole's Hunger Eats a Man never refers to the struggle against apartheid. ${ }^{81}$ It is concerned instead with present deprivation and inequality, although it locates the roots of these conditions in the past and in the structures of white supremacy. It directly brings into the present the question of resistant violence as a response to objective violence. For most of the novel, the characters are trapped in a cycle of poverty, hunger and despair, in which the idea of beauty is invoked through its inaccessibility. The absence of beauty corresponds with the ubiquity of objective violence. The recovery of beauty, pictured in the closing page of the novel, requires a revolutionary change in social and economic relations or, at least, the

\footnotetext{
${ }^{79}$ Ibid., p. 369.

${ }^{80}$ Ibid.

${ }^{81}$ Nkosinathi Sithole, Hunger Eats a Man (Johannesburg, Penguin, 2015).
} 
possibility of imagining such a change. The resolution of the habitual South African dialectic of class is enacted when the people of the rural village of Ndlalidlindoda - the Zulu translates 'hunger eats a man' - invade the middle-class suburb of Canaan. At the same time, the resolution of South Africa's chronic sexual violence is figured in the violent castration by female vigilantes of an offender. In this way, the novel broadens the realm of objective violence to encompass not only racial and class inequality but also coercive forms of male sexuality.

Religion in Hunger Eats a Man provides people with a mechanism to alter material reality. But the different religious practices - prayer, sacrifice or use of medicine - prove to be ineffectual, as the novel unfolds. Religion only reinforces the power of objective violence, through its capacity to mystify. Class struggle is the way to fulfil the promises that religion fails to keep.

The novel is a chilling portrait of conditions in rural South Africa. Ndlalidlindoda is a fixed, static place; it is objective violence solidified. The place cannot escape its name. Ndlalidlindoda feeds on itself; its people starve. As indicated above, the novel mitigates this harsh scenario with two instances of resistance. In the first, a group of village women, in an act of divine violence, castrate two men who have sexually abused close family members. ${ }^{82}$ One of the victims of sexual violence is the ancient, wheelchair-bound mother of the perpetrator, while the other is retarded and defenceless. The women operate as vigilantes in a context in which they can expect no assistance from the criminal justice system, thus 'using the only language men understand - violence'. 83

The second example of transformative action from below occurs in a story written by a schoolboy, Sandile, in which he describes the people from the surrounding area invading and eating all the food they can find. 84 Known as the Killer Bees, they attack anyone who resists. This initial invasion could be described as an act of divine violence. Later, though, when the people of Ndladlindoda join the Killer Bees to invade Canaan, an organising committee plans the action. ${ }^{85}$ The army, waiting to protect private property, is immobilised by classic passive resistance, when a crowd of disabled people is sent out to confront the guns. That the invasion of Canaan is redemptive becomes apparent when the novel closes with a description of rainfall and regeneration. It is notable that both violent and non-violent techniques of resistance are depicted in the closing pages of the novel. Moreover, the hope inspired by the novel does not follow from an actual insurrection but from the capacity to imagine one. Central to this act of imagination is the ability to render the sphere of objective violence visible.

\section{Conclusion}

${ }^{82}$ Ibid., pp. 82-5.

${ }^{83}$ Ibid., p. 105.

${ }^{84}$ Ibid., pp. 152-7.

${ }^{85}$ Ibid., p. 161. 
In the Indian novels I discuss in this article, power and violence pervade all levels of life, from the public to the intimate. People of different classes are subject to power and its repressive ideologies, but the lower the class, the more violent and cruel is the manifestation of power. The middle-class revolutionaries in the Naxal novels are led inexorably towards acts of violence, but tragically these acts achieve nothing but trauma and greater political repression. The Texture of Shadows is less pessimistic about the efficacy of violent resistance, describing as it does a successful liberation struggle. But it details this struggle's ambiguous consequences with relentless precision. Hunger Eats a Man, however, provides a rallying call for new forms of grassroots opposition, both violent and non-violent, as a response to intractable structures of inequality and extreme physical deprivation.

Malreddy argues, in relation to Lowland, that its middle-class protagonist is impelled by a sense of justice and moral outrage to achieve an 'enchanted solidarity' with the Naxalite movement: Udayan's anger is inappropriately displaced to the Naxalite cause. This phenomenon does not present itself in the same way in the two South African novels. Solidarity is already chosen for most people by virtue of their race. Betrayal of this solidarity, often as a result of torture, is more the issue than misplaced or enchanted solidarity.

Resistance, Hunger Eats a Man reminds us, can take both non-violent and violent forms. For Žižek, organised non-violent resistance to objective violence is itself violent. Because objective violence does not entail physical violence - for as soon as it does it becomes subjective violence conscious violation of the order of objective violence enters into its logic of violence without a subject. While the aims and effects of revolutionary violence and non-violent resistance might be equated - and Balibar, too, regards non-violence simply as 'an inversion' of violence ${ }^{86}-$ the Indian novels suggest that it is chiefly the use of actual physical violence by revolutionary agents, especially if they are driven by a naive, enchanted solidarity with the oppressed and by doctrines of revolutionary utopianism, that leads to their moral decay and ultimately to their deaths in an abject fashion, stripped of heroism. In South Africa's case, The Texture of Shadows suggests, the consequences of the resort to counter-violence have to be faced and re-incorporated into the national narrative. Both its pathologies and its heroism need to be recognised in a way that goes beyond the mythologised story of national liberation, if objective violence is to be transformed into conditions in the present that will allow for 'a proper moment of civility in politics in order to introduce the demand for anti-violence, or resistance to violence, particularly resistance to that reactive violence that produces violence and allows it to become generalized'. ${ }^{87}$ The analysis of the representation of political violence in the selected texts from the two countries enables the ethical terrain that Balibar maps out to be explored, as it relates to the lived experience of a range of individual protagonists and their interrelationships in specific historical contexts.

\footnotetext{
${ }^{86}$ See É. Balibar, Violence and Civility: On the Limits of Political Philosophy (Columbia, Columbia University Press, 2015), p. 22. In this book, Balibar rejects non-violence, arguing instead for anti-violence or civility, a politics that seeks to ward off cruelty even as it recognises the inherent violence of politics itself.

${ }^{87}$ Ibid., p. 25.
} 


\section{Acknowledgements}

A version this article was first delivered at the Journal of Southern African Studies 'Southern Africa Beyond the West' conference, held in Livingstone, Zambia in August 2015. I was part of a panel tasked with comparing literary texts from two BRICS countries. I should like to thank the organisers of that conference for the invitation to attend, and the anonymous reviewers of this article whose criticisms resulted in significant changes to it. The research that has made this article possible has also been supported by funding from the National Research Foundation (NRF) of South Africa. 